\title{
The Discordance between Antenatal Care Attendance and Skilled Birth Attendant at Delivery in the Niger Delta Region of Nigeria.
}

\author{
Ntiense Macaulay Utuk ${ }^{1, \&}$, Aniekan Monday Abasiattai ${ }^{2}$, Anyiekere M \\ Ekanem $^{3}$, Nsikak Paul Nyoyoko4 \\ ${ }^{1,2,4}$ Dept of Obstetrics and Gynaecology,University of Uyo Teaching Hospital,Uyo. \\ ${ }^{3}$ Dept of Community Medicine, University of Uyo Teaching Hospital, Uyo.
}

\begin{abstract}
Background: Maternal mortality is unacceptably high in Nigeria. A skilled attendant at birth has been recognised as the single best measure against maternal mortality. Yet, a large proportion of woman register for antenatal care services in the hospital but choose to deliver in unorthodox facilities.

Objective: This study aims to determine the reasons why women book for antenatal care in hospitals but don't deliver there, and where they go for delivery.

Methods: This is a cross sectional study using random sampling technique. Semi-structured questionnaires were administered to participants who had consented to the study and the data was analysed using SPSS Windows version 20.0. Significant level was set at $P<0.05$

Results: 378 women participated in the study. The mean age was 27.66 years \pm 5.15 . Most respondent were Christians and most had at least a post secondary level of education. They booked for antenatal care primarily to access care when ill and to receive immunization and be screened for the Human Immunodeffiency Virus. They did not deliver in the hospital because of sudden onset of labour and because labour occurred in the night, as well the fear of caesarean section and high cost of delivery. Most respondents delivered in church,at traditional birth attendants and at home. Those who claimed to deliver in other hospitals were of the minority. There was a statistically significant association between increasing parity and delivery in unorthodox facilities. Conclusion: To encourage deliveries with skilled birth attendants, it is necessary to re-emphasize rigorous, comprehensive health education; incorporate trained TBAs in orthodox health care to encourage timely referral, and equip health centre annexes for churches who offer obstetric care. Also there should be improvement in contraception utilisation and implementation of focused antenatal care.
\end{abstract}

Key Words: Discordance, Skilled birth attendant, Traditional birth attendant, Maternal Mortality

\section{Introduction}

The problem of maternal mortality continues to plague the developing world, Nigeria inclusive and the year 2015 has come and gone but the target of the millennium development goal 5,to reduce maternal mortality by $75 \%$, has not been met[1,2].

The World Health Organization estimates that approximately 600,000 maternal deaths occur worldwide annually, with $99 \%$ of these deaths occurring in the developing world[3]. Nigeria is said to contribute $10 \%$ to the annual estimate of maternal mortality[4]. Indeed,recent statistics still make for grim reading:there were 576 maternal deaths per 100,000 live births between 2008-2013[5]. And for every maternal death, there is, apart from high perinatal wastage, the hidden cost of subsequent problems of fertility and damage to reproductive organs[6].

It is estimated that greater than $80 \%$ of maternal deaths are due to direct obstetric complications i.e haemorrhage, sepsis, hypertensive disorders, unsafe abortion and obstructed labour[7] Most of these conditions cannot be predicted but they can be treated with simple readily available means[8]. These complications occur even in normal pregnancies. Indeed, it has been shown that some women who had apparently normal antenatal periods develop these problems in labour and the peuperium and some of them die[9]. Thus even though antenatal care is an acknowledged measure for reduction of maternal mortality and morbidity, this favourable outcome is noticed in patients who receive antenatal care and deliver in orthodox health care facilities where skilled attendance is available[9]. Thus there is a strong association between skilled care at delivery and lower levels of maternal mortality[10]. In 1999, the United Nations General Assembly recommended that countries use the process indicator of skilled attendant at delivery as a benchmark indicator to measure progress towards reducing maternal mortality and morbidity[11].

Yet in Nigeria,there is a disparity between antenatal care attendance and delivery in orthodox facilities[5,12]; and most women prefer to deliver in churches,at home and in traditional birth attendants places. 
The aim of this study was to determine why women book for antenatal care in the hospital in the first place, but decide to deliver in unorthodox facilities without a skilled attendant. This information, it is hoped will guide programming and initiate measures that will increase the hospital delivery rate among our booked patients and ultimately lead to a reduction in the maternal mortality and morbidity in our environment.

\section{Materials And Methods}

This cross sectional study was conducted between February 2015 and May 2015 in three hospitals in Akwa- Ibom State:Iquita General Hospital, Oron; Saint Luke's Hospital, Anua, Uyo; and the University of Uyo Teaching Hospital after approval of the study by the ethical review committee of the University of Uyo Teaching Hospital. The Iquita General Hospital Oron and the Saint Luke's Hospital, Anua are secondary health care facilities and offer comprehensive emergency obstetric care. All the hospitals are situated in thickly urban populations. Akwa Ibom State is in South-South zone in the Niger Delta of Nigeria with a population of approximately four million people.

The study population were pregnant parous women who booked for antenatal care in their last pregnancy but delivered elsewhere. Primigravid patients were excluded from the study.A cross sectional formula of $\mathrm{N}=\mathrm{Z} 2 \mathrm{pq} / \mathrm{d} 2$ and a $\mathrm{P}$ of $31.5 \%$ was used to determine sample size, being the proportion of women who refused delivery at a health facility because of high cost in Akwa Ibom State of Nigeria Demographic and Health survey, NDHS 2013)

$\mathrm{N}=1.96 \times 1.96 \times 0.315 \times 0.685 / 0.0025=331.6=332$.

Adding $10 \%$ of non response rate $=10 / 100 \times 332=364$.

Three hundred and ninety women were selected in the antenatal clinic by simple random sampling after explanation of the nature of the study and assurance of confidentiality of information given. Pretested, semistructured questionnaires were distributed to consenting women by trained research assistants. The questionnaires had sections on the sociodemographic characteristics of the respondents, their previous place of delivery,reasons for nondelivery in health facilities,the people who decide where the respondents deliver. Three hundred and seventy eight women filled the questionnaires correctly and data analysis was based on these.

Data was analyzed using SPSS for windows version 2.0 (SPSS Inc, Chicago IL, USA) and presented in simple table. Descriptive statistics was done for continuous variables while categorical variables were summarised using frequencies and percentages.

Association between selected variables and place of delivery of respondents was compared using Chisquare. Level of significance was set at $5 \%(\mathrm{P}<0.05)$

\section{Results}

The majority of the respondents were between 20-34 years of age, 303(80.2\%) with a mean age of 27.7years, and were married (96.0\% ) while $226(59.8 \%)$ were unemployed. Only $12(3.2 \%)$ of the respondents did not have a formal education with 236 (62.4\%) having secondary level education. Two hundred and forty two $(64.0 \%)$ of the respondents were resident in an urban area while $136(36.0 \%)$ were residents in rural communities (TABLE 1).

The type of facility the women delivered in their previous pregnancy is shown in TABLE 2 . The church was the most preferred facility for delivery $134(35.4 \%)$. One hundred women (26.5\%) delivered in a TBA's place while $91(24.1 \%)$ delivered at home

The most common reason given by respondents for not delivering in hospital was that labour started in the night $128(33.9 \%)$. Other common reasons included sudden labour 108 (28.6\%), fear of caesarean section 70(18.5\%), no means of transportation 68(18.0\%) and long distance of heath facility 66(17.5\%)(TABLE 3)

In $124(32.8 \%)$ of the cases both patient and her husband decide where delivery will take place. In 124(32.8\%) of the cases the patient decides by herself while friends and the pastor are those that decide in $8(2.1 \%)$ respectively. (TABLE 4).

In (TABLE 5) selected variables were explored against the place of last delivery. These included residence(urban or rural) education, employment, distance to facility, and parity. Only increasing parity was statistically significant with regard to delivery in unorthodox places.

The reasons the women gave for booking for antenatal care in hospital included to have access to hospital when ill 239(78.6\%), to receive immunisation 71(23.4\%) and to get screened for HIV 45(14.8\%)

\section{Discussion}

This study shows that a lot of our women despite booking for antenatal care still prefer to deliver in unorthodox health facilities. This is in agreement with several other studies[5,13,14].This occurs despite the fact that a skilled birth attendant at delivery has been shown to be essential in reducing maternal mortality and this was not present in such places[15-19]. The majority of the patients were aged between 20 and 34, the peak period of their reproductive life [20]. 
They were mostly resident in urban areas and the majority had at least a secondary school level of education. This is in contrast to several studies which show a positive relationship between mother's education and urban residence and attendance at antenatal care and supervised delivery[21,22]. However, this study was conducted in thickly urban areas were most of the patients live. Also, some studies in a similar society such as ours, have shown that formal education may not change the faith of a highly educated woman[23,24].

Most of these patients were unemployed. This is in agreement with other studies which show the relationship between financial capability and supervised delivery in health care facility $[25,26]$.The poorer the patient is the less likely she is to access skilled care.The study showed that most of the women delivered in churches or at traditional birth attendant. This is in agreement with other studies conducted in the Niger Delta Region of Nigeria[27-30]. The role of spiritual churches in antenatal clinic default has been elucidated[31]. This is even so when it has been demonstrated that when women deliver in these churches, the outcome is worse that delivery anywhere else[31]. The reasons adduced for the patronage of these churches include spiritual attack by wicked people, prophetic warning from the church and divine blessings for the babies born in the church[31]. Indeed, it has been found that the need for divine intervention in the labour process may drive these parturients to church [32].

As much as $22 \%$ of deliveries in Nigeria are conducted by TBA`s even though there is a high incidence of complications in such deliveries[5]. The presence and role of TBA's in rural areas is well-known, especially because here there are inadequate health facilities and skilled attendants[33]. What is less well known is the presence and utlisation of these TBA's in urban areas[34]. This is illustrated in this study and emphasises the strong cultural affinity for these services. Kleinman has demonstrated how the difference between a medical model, considered intrinsically alien, and strong cultural belief systems can impair orthodox health seeking behaviour[35]. TBA's are more culturally attuned to the belief systems of patients and are seen to be more empathetic, as well as cheap.They are therefore heavily patronised. Restricted socio-cultural gender roles for women, may further drive these women to deliver in TBAs.

The common reasons given for not coming to the hospital to deliver include sudden labour/labour at night, fear of caesarean section, no means of transportation, long distance of health facility and high cost.

Birth preparedness and complication readiness is the process of planning for normal birth and anticipating the actions needed in an emergency[36]. It is hoped that with the implementation of focused antenatal care,which includes birth preparedness, sudden labour and labour at night will no longer serve as a reason for not delivering in hospitals.

Fear of caesarean sections was another major reason for not delivering in hospitals. This is supported by several studies[37-39]. The reasons given for opposition to caesarean section include denial of womanhood, fear of scorn from other women, and the risk of dying from the procedure.It is therefore necessary to educate the people on the role caesarean section plays as an alternative to hazardous vaginal delivery, and to critically examine caesarean delivery and suggest alternative measures where feasible[30] .

Financial constraints and lack of transportation are also major obstacles to accessing skilled attendance at delivery as shown in this study.This agrees with other studies[40,41]. It is therefore essential that pregnant women and their family save money for delivery. However, the issue of transportation may go beyond good roads . Institutional barriers, including financial cost and socio-cultural factors, may limit the advantage of shorter distances[42].

In a majority of instances in this study the husband decides where the woman delivers. This underlines the need to involve the husband personally in every decision about management of the patient.

In table 5, the association between selected variables and place of last child delivery was explored. Only increasing parity was found to be statistically significant for delivery in unorthodox places. Indeed, the latest report from the national demographic and health study shows that birth order,with increasing parity, is inversely associated with the likelihood of a birth being assisted by a health care provider[5].

Thus, it is shown that social, cultural, economic and political, biological consideration modulate the behaviour of pregnant women who seek care. This complex interaction means that even when skilled care is available some women may not seek it, or receive it[22].

\section{Conclusion}

To reduce the maternal mortality rate, every woman should have a skilled attendant at birth. However a significant proportion of our women continue to deliver in unorthodox places even after booking for antenatal care in hospitals.To discourage women from delivering in unorthodox facilities or make it safer we recommend as follows:

: Continuous and rigorous health education on the benefits of delivering with a skilled attendant. This education should not only be personal,but also communal.

: Raising womens status through sustainable poverty alleviation programs as well as eradication of poverty. 
: Reducing the cost of health care generally, and through a national health insurance scheme which extends to the grassroots, not just civil servants.

: Training and retraining TBAs to recognise signs of difficult labour and encourage them to refer to orthodox care.

: Setting up of a properly equipped health facility,with government oversight functions, near churches which engage in obstetric practices.

: Education of the community on the importance and safety of caesarean section as an alternative to hazardous vaginal delivery.

: Enlightenment to improve on the current contraception utilisation of $2 \%{ }^{5}$ to limit family size.

: Comprehensive implementation of focused antenatal care.

What is known about this topic.

- A skilled birth attendant at birth is necessary to reduce maternal mortality.

- Most women in Nigeria deliver in unorthodox places were skilled birth attendants are lacking.

- Traditional birth attendants are patronised mostly in rural areas where health care facilities are lacking.

What this study adds.

- Traditional birth attendants are heavily patronised in urban areas.

- Increasing parity is associated with delivery in unorthodox places.

- Socio-cultural factors may prevent educated women from accessing health in orthodox facilities.

\section{References}

[1]. Ndep AO. Informed community participant essential to reducing Maternal Mortality in Nigeria. International journal of Health and Psychology research. 2014 March; 2(1): 26-33.

[2]. Igbase GO,Ebeigbe PN. Maternal Mortality in a rural referral hospital in the Niger Delta,Nigeria. J. Obstet Gynaecol.2007Apr;27(3):257-278.

[3]. World Health Organisation. Maternal mortality ratios and rates; a tabulation of available information. $3^{\text {rd }}$ Edition. Maternal health and safe motherhood program,WHO. 1991.

[4]. Shiffman J, Okonofua F. The state of political priority for safe motherhood in Nigeria. Br. J. Obstet. Gynecol.2007 Feb; 114(2):127133.

[5]. National Population Commission. Nigeria Demographic and Health Survey. 2013. Maryland: NPC Nigeria; 2014.

[6]. Mahler H.The safe motherhood initiative:a call to action. Lancet. 1987; 1(8534):668-670.

[7]. Sule-Odu AO. Maternal Deaths in Sagamu, Nigeria. Int J Gynecol Obstet. 2000; 69:47-49.

[8]. World Health Organisation. Mother-baby package; implementing safe motherhood in countries. Geneva;WHO/FHE/MSM/94.11/1994.

[9]. Lennox CE. Assessment of Obstetric high risk factors in a development country. Trop Doc. 1984 July;14(3):125-129.

[10]. Harrison KA. Obstetric fistula: one social calamity too many.. Br J Obstet Gynaecol. 1983 May; 90(5):385-386.

[11]. Ransom EI,Yinger NV. Making motherhood safer:overcoming obstacles on the pathway to care.2002.Measure communication. Population Reference Bureau. Washington DC.

[12]. WHO/UNICEF: Antenatal care in developing countries. Promises, achievements and missed opportunities. Analysis of trends, levels and differentials 1990-2001. 2003, WHO,Geneva.

[13]. Starrs A. Delivering for Women. The lancet. 2007 Oct; 370 (9595): 1285-1287.

[14]. Erim Do, Kolapo UM, Resch SC. A rapid assessment of the availability and use of Obstetric Care in Nigerian Health Care Facilities. PLOS one 7(6): e 39555. Doi10.1371/journal. Pone.0039555.

[15]. UNICEF MDG. Goal: Improve Maternal Health. UNICEF/HQ04-1219/Vitale.

[16]. WHO. Making Pregnancy Safe. Maternal Mortality. World Health Organisation:2011.

[17]. Oye-Adeniran B, et-al. Causes of Maternal Mortality in Lagos state. Annals of Tropical Medicine and public Health 2014. 7(3): $177-181$.

[18]. Ekele BA, Tunau KA. Place of delivery among women who had antenatal care in a Teaching Hospital. Acta Obstetricia et gynaecologica Scandinavica. 2007; 86(5):627-630.

[19]. Bour D, Bream K. An analysis of the determinants of Maternal Mortality in Sub-Saharan Africa. J. Women's Health (larchmt) 2004 Oct; $13: 926-38$.

[20]. Udoma EJ, Ekanem AD, Abasiattai AM, Bassey EA.Reasons for preference of delivery in church-based clinics by women of southsouth Nigeria. Nigerian Journalists of Clinical Practice. 2008;11(2) :100-103.

[21]. Wong E.L: Accessibility,quality of care and prenatal care use in the Philippines. Social science and medicine 1987; 24(11):927-944

[22]. Kwast B.E, Rochart R.W, Kidang-Mariam .W. Maternal Mortality in Addis Ababa, Ethopia. Stud Fam plan. 1986 Nov; 17(6): 288301 .

[23]. Udoma EJ,Asuquo EEJ, Ekott MI. Maternal Mortality from Obstructed Labour. The Role of Spiritual Churches. Int J Obstet Gynae. 1999 Nov;67(2):103-105.

[24]. Udoma EJ,John ME,Udosen GE, Udo AE. Obstetrics practices in spiritual churches in South Eastern Nigeria. Mary Slessor Jour Med Sc. 2003. 3(2):51-56.

[25]. Udoma EJ, Ekanem AD,John ME, Eshiet AT. The role of institutional factors in maternal mortality from obstructed labour. Global Journal Med Sc.2003;2(1): 113-17.

[26]. Adetunji JA. Church-based obstetric care in Yoruba community. Soc Sc Med. 1992.35(90):1171-1178

[27]. Etuk SJ, Asuquo EEJ, Ekanem AD. Maternal mortality following caesarean section at the University of Calabar Teaching Hospital, calabar, Nigeria. Nig J Med.1999; 8:62-65.

[28]. Sule-Odu AO, Fakoya TA, Adetoro OO. Destructive obstetric operations at a University Hospital in Nigeria. Nig Postgrad Med J, 1996;3: 43-45.

[29]. Okonofua FE, Makinde ON, Ayangade SO. Yearly trends in caesarean section and caesarean mortality at Ile-Ife, Nigeria. Trop J Obset Gynaecol, 1988;1(1):31-35. 
[30]. Harrison K. Maternal mortality in Nigeria: the real issues. Afr J Reprod Health, 1997;1(1): 7-13.

[31]. Etuk SJ, Itam IH, Asuquo EE. The role of Spiritual Churches in Antenatal Clinic default in Calabar, Nigeria. East African Medical Journal. 1999 Nov; 76(11): 639-643.

[32]. Olusanya BO, Alakija OP, Inem VA. Non-Uptake of facility-based Maternity services in an inner-city community in Lagos,Nigeria: an observational study. J Biosoc Sci.2010 May;42(3):341-58.

[33]. Oshonowoh FE, Nwankwo GC, Ekiyor CP. Traditional birth attendants and womens health practices:A study case of Patani in Southern Nigeria. J Public Health and Epidemiology.2014;6(8):252-261.

[34]. Itina SM. Characteristics of traditional birth attendants and their belief and practices in Ofot Clan, Nigeria. Bull World Health Organization; 75(6):537-538

[35]. Kleinman A. Concepts and a model for the comparison of medical systems as cultural systems.Soc Sci Mes. 1978;12:85-93.

[36]. Ekabua JE, Ekabua KJ, Odusolu P, et al. Awareness of Birth Preparedness and Complication Readiness in Southeastern Nigeria. ISRN Obstetrics and Gynaecology. 2011(2011); Article ID 560641, 6 pages: http:/dx. Doi.org/10.5402/2011/560641.

[37]. Ezechi OC, Nwokoro CA, Kalu BKE, Njokanma OF, Okeke GCE. Caesarean morbidity and mortality in a private hospital in Lagos Nigeria. Trop J Obset Gynaecol, 2002;19(2):97-100.

[38]. Adeleye JA. Primary elective caesarean section in Ibadan, Nigeria. International Surgery. 1977 Feb; 62(2): $97-99$

[39]. Lawson JB. Caesarean section. In Obstetrics and Gynaecology in the Tropics edited by Lawson JB and Stewart DB. London.1967;pp. 184-186.

[40]. Ekanem EI, Etuk SJ, Ekanem AD,Ekabua JE. The impact of motorcycle accidents on the obstetric population in Calabar, Nigeria. Trop J Obstet Gynae .2005;222(2):164-167.

[41]. Ekwempu CC, Maine D, Olorukoba MB, Essien ES, Kisseka MN. Structural adjustment and health in Africa. The Lancet. 1990 July; 336(8706):56-57.

[42]. Airey T. The impact of road construction in hospitals in patient catchments in the District of Kenya. Social Science and Medicine. 1989;29(1):95-106

\section{Results}

Table1. Sociodemographic Characteristics Of Respondents: N=378

\begin{tabular}{|c|c|c|}
\hline Characteristics & Frequency & Percentage \\
\hline $\begin{array}{l}\text { Religion } \\
\text { Christians } \\
\text { Islam } \\
\end{array}$ & $\begin{array}{l}376 \\
2 \\
\end{array}$ & $\begin{array}{l}99.5 \\
0.5 \\
\end{array}$ \\
\hline $\begin{array}{l}\text { Age group } \\
\text { Less than } 20 \\
20-34 \\
35-49 \\
\end{array}$ & $\begin{array}{l}25 \\
303 \\
50 \\
\end{array}$ & $\begin{array}{l}6.6 \\
80.2 \\
13.2 \\
\end{array}$ \\
\hline $\begin{array}{l}\text { Educational Status } \\
\text { No formal education } \\
\text { Primary education } \\
\text { Secondary education } \\
\text { Post secondary education }\end{array}$ & $\begin{array}{l}12 \\
74 \\
236 \\
56 \\
\end{array}$ & $\begin{array}{l}3.2 \\
19.6 \\
62.4 \\
14.8 \\
\end{array}$ \\
\hline $\begin{array}{l}\text { Marital Status } \\
\text { Married } \\
\text { Single } \\
\text { Divorced } \\
\text { Widow } \\
\end{array}$ & $\begin{array}{l}96.0 \\
12 \\
1 \\
2 \\
\end{array}$ & $\begin{array}{l}96.0 \\
3.2 \\
0.3 \\
0.5 \\
\end{array}$ \\
\hline $\begin{array}{l}\text { Employment Status } \\
\text { Employed } \\
\text { Not employed } \\
\end{array}$ & $\begin{array}{r}152 \\
226 \\
\end{array}$ & $\begin{array}{l}40.2 \\
59.8 \\
\end{array}$ \\
\hline $\begin{array}{l}\text { Residence } \\
\text { Urban } \\
\text { Rural } \\
\end{array}$ & $\begin{array}{l}242 \\
136 \\
\end{array}$ & $\begin{array}{l}64.0 \\
36.0 \\
\end{array}$ \\
\hline $\begin{array}{l}\text { Parity } \\
1 \\
2-4 \\
5 \text { and above }\end{array}$ & $\begin{array}{l}119 \\
229 \\
30\end{array}$ & $\begin{array}{l}31.5 \\
60.6 \\
7.9\end{array}$ \\
\hline
\end{tabular}

TABLE 2: Previous Place Of Delivery Of Respondents: N: 378

\begin{tabular}{|l|l|l|}
\hline CHARACTERISTICS & FREQUENCY & PERCENTAGE \\
\hline Church & 134 & 35.4 \\
\hline TBA & 100 & 26.5 \\
\hline Home & 91 & 24.1 \\
\hline Unknown maternity homes & 53 & 14.0 \\
\hline
\end{tabular}


TABLE 3 : Reasons For Non Delivery In Health Facilities: N:378

\begin{tabular}{|l|l|l|}
\hline REASONS & FREQUENCY & PERCENTAGE \\
\hline Labour at night & 128 & 33.9 \\
\hline Sudden labour/delivery & 108 & 28.6 \\
\hline Fear of caesarean section & 70 & 18.5 \\
\hline No means of transport & 68 & 18.0 \\
\hline Long distance of heath facility & 66 & 17.5 \\
\hline High cost & 65 & 17.2 \\
\hline Staff on strike & 50 & 13.2 \\
\hline Delays at heath facility & 43 & 11.4 \\
\hline Previous deliveries not in hospital & 38 & 10.1 \\
\hline Poor staff attitude & 34 & 9.0 \\
\hline Disallowed by family members & 28 & 7.4 \\
\hline Forbidden by the voice of God & 27 & 7.1 \\
\hline Care providers not compassionate & 27 & 7.1 \\
\hline No staff at night & 23 & 6.1 \\
\hline Poor quality of service & 20 & 5.3 \\
\hline Lack of staff & 16 & 4.2 \\
\hline Poor privacy & 13 & 3.4 \\
\hline Secrets not maintained & 4 & 1.1 \\
\hline
\end{tabular}

TABLE 4: WHO DECIDES WHERE WOMEN DELIVER: N: 378.

\begin{tabular}{|l|l|l|}
\hline VARIABLES & FREQUENCY & PERCENTAGE \\
\hline Both wife and husband & 125 & 33.1 \\
\hline Myself (wife) alone & 124 & 32.8 \\
\hline Others & \multicolumn{1}{|c|}{82} & 21.7 \\
\hline Wife's mother & 26 & 6.9 \\
\hline Friends & \multicolumn{1}{|c|}{8} & 2.1 \\
\hline Pastor & 8 & \\
\hline
\end{tabular}

TABLE 5: Association Between Selected Factors And Place Of Delivery Of Last Child: N:378

\begin{tabular}{|c|c|c|c|c|c|c|}
\hline \multirow[t]{2}{*}{ VARIABLES } & \multicolumn{4}{|c|}{ PLACE OF DELIVERY } & \multirow[t]{2}{*}{ TOTAL } & \multirow{2}{*}{$\begin{array}{l}\text { TEST OF } \\
\text { STATISTICS AND } \\
\text { STATISTICAL } \\
\text { VALUES }\end{array}$} \\
\hline & HOME & TBA & CHURCH & HOSPITAL & & \\
\hline $\begin{array}{l}\text { Age group(yrs) } \\
\text { Less than } 20 \\
20-34 \\
35-49 \\
\end{array}$ & $\begin{array}{l}4(4.4) \\
74(81.3) \\
13(14.3) \\
\end{array}$ & $\begin{array}{l}11(11.0) \\
79(79.0) \\
10(10.0)\end{array}$ & $\begin{array}{l}10(7.5) \\
108(80.6) \\
16(11.9) \\
\end{array}$ & $\begin{array}{l}0(0.0) \\
42(79.2) \\
11(20.8)\end{array}$ & $\begin{array}{l}25 \\
303 \\
50 \\
\end{array}$ & $\begin{array}{l}X^{2} 10.581 \\
D F 6 \\
P=0.086\end{array}$ \\
\hline $\begin{array}{l}\text { Residence } \\
\text { Urban } \\
\text { Rural }\end{array}$ & $\begin{array}{l}53(58.2) \\
38(41.8)\end{array}$ & $\begin{array}{l}68(68.0) \\
32(32.0)\end{array}$ & $\begin{array}{l}81(60.4) \\
53(39.6)\end{array}$ & $\begin{array}{l}40(75.5) \\
13(24.5)\end{array}$ & $\begin{array}{l}242(64.0) \\
136(36.0)\end{array}$ & $\begin{array}{l}X^{2} 5.767 \\
D F 3 \\
P=0.124\end{array}$ \\
\hline $\begin{array}{l}\text { Employment } \\
\text { Employed } \\
\text { Unemployed }\end{array}$ & $\begin{array}{l}40(44.0) \\
51(56.0)\end{array}$ & $\begin{array}{l}35(35.4) \\
64(64.6)\end{array}$ & $\begin{array}{l}54(41.2) \\
77(58.8)\end{array}$ & $\begin{array}{l}22(41.5) \\
31(58.5)\end{array}$ & $\begin{array}{l}151 \\
223\end{array}$ & $\begin{array}{l}X^{2} 1.589 \\
D F 3 \\
P=0.659\end{array}$ \\
\hline $\begin{array}{l}\text { Education } \\
\text { No formal edu } \\
\text { Primary } \\
\text { Secondary } \\
\text { Post sec. }\end{array}$ & $\begin{array}{l}3(3.3) \\
20(22.0) \\
59(64.8) \\
9(9.9)\end{array}$ & $\begin{array}{l}5(5.0) \\
23(23.0) \\
58(58.0) \\
14(14.0)\end{array}$ & $\begin{array}{l}4(3.0) \\
28(20.9) \\
83(61.9) \\
19(14.2)\end{array}$ & $\begin{array}{l}0(0.0) \\
3(5.7) \\
36(67.9) \\
14(26.4)\end{array}$ & $\begin{array}{l}12(3.2) \\
74(19.6) \\
236(62.4) \\
56(14.8)\end{array}$ & $\begin{array}{l}X^{2} 16.026 \\
D F 9 \\
P=0.066\end{array}$ \\
\hline $\begin{array}{l}\text { Religion } \\
\text { Christians } \\
\text { Islam }\end{array}$ & $\begin{array}{l}91(100.0) \\
0(0.0)\end{array}$ & $\begin{array}{l}98(98.0) \\
2(2.0)\end{array}$ & $\begin{array}{l}134(100 .) \\
0(0.0)\end{array}$ & $\begin{array}{l}53(100.0) \\
0(0.0)\end{array}$ & $\begin{array}{l}376 \\
2\end{array}$ & $\begin{array}{l}X^{2} 5.590 \\
D F 3 \\
P=0.214\end{array}$ \\
\hline $\begin{array}{l}\text { Distance to Facility } \\
<30 \text { minutes } \\
>=30 \text { minutes }\end{array}$ & $\begin{array}{l}43(47.3) \\
48(52.7)\end{array}$ & $\begin{array}{l}59(59.0) \\
41(41.0)\end{array}$ & $\begin{array}{l}73(54.5) \\
61(45.5)\end{array}$ & $\begin{array}{l}30(56.6) \\
23(43.4)\end{array}$ & $\begin{array}{l}205 \\
173\end{array}$ & $\begin{array}{l}X^{2} 2.825 \\
D F 3 \\
P=0.424\end{array}$ \\
\hline $\begin{array}{l}\text { Employment } \\
\text { Employed } \\
\text { unemployed }\end{array}$ & $\begin{array}{l}40(44.0) \\
51(56.0)\end{array}$ & $\begin{array}{l}35(35.4) \\
64(64.6)\end{array}$ & $\begin{array}{l}54(41.2) \\
77(58.8)\end{array}$ & $\begin{array}{l}22(41.5) \\
31(58.5)\end{array}$ & $\begin{array}{l}151 \\
223\end{array}$ & $\begin{array}{l}X^{2} 1.589 \\
D F 3 \\
P=0.659\end{array}$ \\
\hline $\begin{array}{l}\text { Parity } \\
1 \\
2-4 \\
5 \text { and above }\end{array}$ & $\begin{array}{l}35(38.5) \\
47(51.6) \\
9(9.9)\end{array}$ & $\begin{array}{l}40(40.0) \\
55(55.0) \\
5(5.0)\end{array}$ & $\begin{array}{l}38(28.4) \\
82(61.2) \\
14(10.4)\end{array}$ & $\begin{array}{l}6(11.3) \\
45(84.9) \\
2(3.8)\end{array}$ & $\begin{array}{l}119 \\
229 \\
30\end{array}$ & $\begin{array}{l}X^{2} 21.615 \\
D F 6 \\
P=0.001 * *\end{array}$ \\
\hline
\end{tabular}

**Statistically significant $p$ value. 